\title{
UNA RELACIÓN PRÁCTICA ENTRE EL TIEMPO PASADO Y EL ESPACIO ACTUAL \\ Gonzalo Suárez Belmont*
}

Mi nombre completo es Gonzalo Tomas Suárez Belmont. Para saber si en mí ha pasado el tiempo debo hacerles saber el significado de mi nombre. Mi primer nombre, Gonzalo, es de origen visigodo, Gundisalvus, que quiere decir "el que lucha como guerrero".

Mi segundo nombre es Tomás. No sé si por Santo Tomás de Aquino, por Santo Tomás Moro o por el apóstol. Si fuese Santo Tomás de Aquino, lo poco que leí me llevó a equilibrar la razón con la fe e incursionar en la antropología. Si fuese por Santo Tomás Moro, también la lectura de una pequeña parte de su obra me permitió equilibrar derecho con justicia. Y si fuese por Santo Tomás Apóstol, me llevó a considerar no creer lo que no pasase por mis sentidos, en pocas palabras, a "ver para creer".

Mi nombre en náhuatl es Tepecuauyolotl, que significa "el que lleva en su corazón las montañas y los bosques". En fin, el tiempo une el destino de las personas y va forjando su carácter.

Se ha dicho que el tiempo no existe, que se trata de un invento o creación humana y con mis escasas luces y escepticismo trato de razonar sobre el tema. Me remonto a la Grecia clásica y me encuentro a kairos y a cronos. Kairos resulta un concepto cualitativo, "lo que

* Departamento Académico de Derecho, ITAM. 
sucede en el momento adecuado u oportuno", lo que podría esperarse. Y cronos es un concepto cuantitativo: "lo que es preciso".

En nuestro fabuloso y muchas veces enigmático pasado prehispánico representado en su último momento por el esplendor del pueblo tenochca, se separaba el tiempo del hombre con su medición de dieciocho veintenas o sea un total de 360 días, más cinco días nemotemi, ese lapso era el xiuh pohualli. El tiempo de la naturaleza, cuando germinan las plantas, se gesta un ser humano y se agoraba su futuro, veinte trecenas para un total de 260 días, era el tonalpohualli.

En la contemporaneidad nos encontramos a Heidegger, que en su obra Ser y tiempo nos permite solazarnos con un hermoso razonamiento que anoto textualmente:

[E]l pasado tiene siempre un sentido visto solo desde un presente. Lo pasado no solo no es más, considerado desde nosotros, sino que también fue algo distinto de lo que somos nosotros y nuestro concepto vital hoy en el presente [...] solo cuando la otroridad cualitativa de tiempos pasados se abre paso en la conciencia de un presente se ha despertado un sentido histórico [...] pero existe la gran separación temporal entre el historiador y su objeto [...] Si él la quiere representar tiene que tener de alguna manera el objeto ante sí. Se trata de superar el tiempo, y desde el presente, por encima del abismo temporal, aclimatarse en el pasado [... ${ }^{1}{ }^{1}$

En tal tesitura, me siento como un pequeño resumen del pasado, pues por muchos siglos he estado ligado con esta zona del Valle de México.

Interpretando la cadena genética, algo me dice que estuve en un calmecac de la ciudad de Teotihuacán, creo que hoy lo conocen como "la Ventilla". Ahí pintados en el piso de un patio cuadrangular, me enseñaron los dibujos de las trecenas del tonalpohualli; es decir, quedó en mí una interpretación del tiempo y creo que esos conocimientos me indujeron a buscar con inquietud el camino de la antropología.

Casi mil años después, seguramente algunos ancestros desarrapados, hambrientos y codiciosos fueron despreciados por maxtla, el

${ }^{1}$ Martin Heidegger, El concepto de tiempo en la ciencia histórica, traducción Elbio Caletti, p. 369, en <http://philosophersdesk.blogspot.mx/2009/08/martin-heidegger-el-conceptode-tiempo.html $>$. 
cacique de Azcapotzalco, quien les concedió un terreno pedregoso formado por la lava del Xitle en los límites de Tenanitla (San Ángel), poblado por sabandijas, alimañas y serpientes. Pero no obstante esos peligros, se impusieron a la adversidad, mostrando su dominio en ese sitio que era conocido como Tizapán.

Tiempo después, algún otro de mis ancestros luchó en Culhuacán (parte del señorío de Coyoacán) adoptando y adaptando los elementos culturales del último reducto tolteca, donde se me enseñó el arte adivinatorio y me convirtieron en algún tlamatinime para conducir a los guerreros jóvenes

Seguramente también los portadores de mis remotos genes estuvieron cuando los ya para entonces llamados mexicas fundaron Tenochtitlán y el grupo disidente se separó y estableció la ciudad gemela de MéxicoTlatelolco (por cierto, ahí fue donde nací en el siglo XX).

Sentí la desolación cuando el último reducto de la defensa de Tlatelolco cayó en manos de Hernán Cortés y sus capitanes, pero gracias a Bernardino de Sahagún, otro portador de mis genes aprendió el alfabeto latino y posiblemente auxilió a los informantes sobre el mundo perdido y por lo que nuevamente asumí tareas de enseñanza. Ahora me apellidaría Suárez.

Creí que ahí terminaba mi vida por el mundo tangible, cuando el destino me trajo nuevamente a San Ángel por un pleito del tesorero real en contra de un benefactor que construiría la capilla mortuoria del convento carmelita de San Ángel. Estamos refiriéndonos al año de 1685, cuando me ostentaba con el rimbombante título de "Licenciado Gonzalo Suárez de San Martín del Consejo de su Majestad, su Oidor en esta Real Audiencia y Juez Comisario privativo del derecho de media annata". Creo que ahí empezó mi incursión por el campo del derecho, claro que Tomás Moro me hubiera reprobado.

Transcurrió otro siglo y medio y al parecer, con el movimiento de independencia, se perdió la pista de mi tiempo y espacio ganados.

De lo que tengo gran duda es de si mi apellido francés Bel Mont, que no Belmont, llegó con las tropas francesas que intervinieron en la Guerra de los Pasteles o cuando los conservadores ofrecieron el trono 
de México. Lo que sí sé es que un bisabuelo mío reposa en el Panteón Francés de la Piedad, creo que ahí puede asomar otra pista de mi espacio en el tiempo.

Luego se me despierta otra incertidumbre. Si mi apellido Belmont, ahora sajón, llegó con algún soldado invasor en la Guerra del 48. Lo que sé es que el mexicano o el norteamericano luchó en Padierna, límites de San Ángel con Tlalpan o pudo ser también en Churubusco. De lo que sí me platicaron es que los Belmont, durante la segunda parte del siglo XIX y principios del XX, poseían solares en Coyoacán. ¡Huy!, ahora sí. Para nuestros colegas maestros de historia, si acaso fuere de su interés, se presenta la oportunidad de sumar una nueva casta: indio, español, francés, norteamericano, ¿cómo la podrían denominar?

En un pasado más reciente y del que guardo las pruebas necesarias, tuve el privilegio de ser un estudiante al que le tocó la inauguración, en 1954, de la Ciudad Universitaria e iniciar los cursos en la Facultad de Derecho, por lo que mi existencia física ocupa nuevamente un espacio en el Pedregal de San Ángel.

En momento posterior se me invitó a formar parte de una institución educativa, el Instituto Tecnológico Autónomo de México. Si las neuronas no me fallan, parece que fue en enero de 1972, y aunque ya había incursionado por la secundaria y el bachillerato, ahora era un reto aplicar en el ámbito de la educación superior mis escasas habilidades.

Plantel de Marina Nacional, barrio de Santa Julia de fama nada recomendable, edificio y aulas nuevas, que supongo en nada se parecería a los campus previos de Palma Norte o Serapio Rendón. Ahora con estacionamiento para una treintena de automóviles y con grupos de no más de 20 alumnos interesados en los nuevos programas diseñados y estructurados por Estudios Generales, los que les ayudarán a desarrollar nuevas aptitudes, razonarlas en el ámbito de la filosofía y aplicarlas en la solución de problemas reales. Con ese proyecto se fue transformando al alumno de una simple grabadora de datos en un individuo interesado en conocer a la sociedad para brindarle mejores servicios profesionales.

En 1978 retorné una vez más a Tenanitla. La mudanza a un nuevo campus, Río Hondo, Tizapán. El departamento de Estudios Generales 
crece. Nuevas materias, nuevo reto, oportunidad para actualizarme, conocer el pensamiento económico, político y social de México. Tratar de aplicar el ejercicio del método dialógico con los alumnos, confesando que muchos minutos de clase los acaparaba con un monólogo ilustrativo. Recuerden que dije que yo no creía sino hasta que comprobaba.

En 1980 el Instituto me brindó la oportunidad de colaborar con el entonces recientemente estructurado Departamento de Derecho. Doble orgullo, porque ahora podría transmitir a los alumnos el sentido y espíritu de las normas jurídicas laborales aplicadas a la realidad del mercado de trabajo.

Me considero un ser imperfecto. Pienso muchas veces que no logro empatar con los cambiantes ideales, sentimientos y necesidades de nuestros jóvenes alumnos, pero el contacto con ellos me ha hecho, como montañista que fui, tratar de lograr la cumbre no importando el camino escabroso, la fatiga, el clima, la enfermedad y a veces la incomprensión de alguna generación por no lograr despertarle el interés.

Estoy convencido de que el tiempo y el espacio tienen una relación. He heredado de mis ancestros portadores de mis genes desde el pasado prehispánico, la etapa virreinal y la República, el amor por la naturaleza, la espiritualidad y riqueza cultural, la fuerza y la lógica de la norma jurídica, pero sobre todo la tenacidad con la que emprendo la tarea diaria de mi vocación como maestro, todo ese tiempo conjugado con el espacio, Tizapán, Tenanitla, Coyoacán.

Colaboro con el Tecnológico Autónomo de México, considerado como institución de muy alto nivel en el ámbito de la formación profesional, por lo que traigo a la memoria el siguiente juramento que se pronunciaba en la universidad del siglo XVI:

Seré obediente al rector y a los demás que le sucedieren y en lo futuro ejercieren el propio cargo y empleo de señores rectores [...] y que en los negocios y hechos de la universidad daré fiel consejo y ayuda y favor sin darlo jamás contra la propia universidad y sus bienes, que asimismo vendré cuantas veces fuere necesario y no participaré en reunión alguna contra las constituciones y estatutos. 
Como profesor, con casi 43 años de tener a mi cargo la impartición de diversas materias, tanto de los programas del Departamento de Estudios Generales como del Departamento de Derecho, les mandaría a los estudiantes un mensaje del que es autor Juan Bautista Balli en 1596:

Vivís en una ciudad y pertenecéis a una universidad muy floreciente en todo tipo de virtudes y de méritos, en las cuales, como dijo aquel autor respecto de la ciudad de Atenas, no podéis entrar en ningún templo, en ninguna plaza, en ningún palacio, ni en ningún lugar, sin poner vuestra planta sobre alguna huella de virtud.

Con motivo de este homenaje del que soy objeto por mi cuadragésimo segundo aniversario como maestro de asignatura en el Instituto Tecnológico Autónomo de México, aprovecho para dar las gracias al señor Rector Arturo Fernández Pérez, al Vicerector Alejandro Hernández Delgado, a los jefes de los Departamentos de Estudios Generales y de Derecho, doctores Carlos McCadden y Jorge Cerdio, a los colegas maestros de la mesa doctores Raúl Figueroa Esquer, José Manuel Orozco Garibay y Luis R. Raigosa, en especial a los doctores José Ramón Benito Alzaga y Carlos de la Isla Veraza y a los demás que me honran con su presencia, al personal administrativo y de intendencia, a los que son y han sido mis alumnos, a mis amigos, a mis familiares, a mi esposa María Luisa, a mis hijos Gonzalo y Mauricio, que creo seguirán con la tarea de ser espectadores y a la vez actores conjugando el tiempo con el espacio.

Muchas gracias. 